\title{
PENGARUH UTAMA APLIKASI BOKASHI LIMBAH PADAT KELAPA SAWIT DAN NPK ORGANIK PADA TANAMAN TERONG
}

\author{
Sumitro $^{1}$ T. Rosmawati ${ }^{2}$ Ernita $^{3}$ \\ Jurusan Agroteknologi, Fakultas Pertanian, Universitas islam Riau, Pekanbaru, Riau. \\ Dosen Agroteknologi, Fakultas Pertanian, Universitas islam Riau, Pekanbaru, Riau. \\ Dosen Agroteknologi, Fakultas Pertanian, Universitas islam Riau, Pekanbaru, Riau.
}

\begin{abstract}
Abstrak
Penelitian telah dilaksanakan di kebun percobaan Fakultas Pertanian Universitas Islam Riau, Jalan Kaharudin Nasution KM 11, Kelurahan Simpang Tiga, Kecamatan Bukit Raya, Kota Pekanbaru. Penelitian telah dilakukan selama 5 (lima) bulan terhitung bulan Januari sampai Mei 20I5. Penelitian bertujuan untuk mengetahui pengaruh interaksi maupun pengaruh utama aplikasi bokashi limbah padat kelapa sawit dan NPK Organik pada tanaman terong.
\end{abstract}

Penelitian menggunakan Rancangan Acak Lengkap 4x4 faklorial yang masing-masing dengan 3 ulangan. Faktor-faktor tersebut adalah faktor $\mathrm{L}$ (dosis bokasi limbah padat sawit) terdiri dari $\mathrm{L} 0=0 \mathrm{~g} / \mathrm{plot}, \mathrm{Ll}=$ $1260 \mathrm{~g} / \mathrm{plot}, \mathrm{L} 2=2520 \mathrm{~g} / \mathrm{plot}$ dan $3780 \mathrm{~g} / \mathrm{plot}$ dan faktor $\mathrm{N}$ (dosis pupuk NPK Organik) terdiri dari N0 $=0 \mathrm{~g} /$ tanaman, $\mathrm{Nl}=20$ $\mathrm{g} /$ tanaman, $\mathrm{N} 2=40 \mathrm{~g} /$ tanaman dan N3 = $60 \mathrm{~g} /$ tanaman sehingga diperoleh 48 satuan percobaan. Setiap satuan pecobaan terdiri 4 tanaman dan 2 diantaranya sebagai sampel. Jumlah tanaman seluruhnya adalah 192 tanaman. Parameter yang diamati ialah tinggi tanaman, umur berbunga, umur panen, jumlah buah ekonomis per tanaman, berat buah ekonomis per tanaman dan jumlah buah tidak ekonomis per tanaman.

Hasil penelitian menunjukkan bahwa bokashi limbah padat kelapa sawit dan NPK Organik secara interaksi berpengaruh nyata terhadap seluruh parameter pengamatan dengan perlakuan terbaik pada pemberian bokashi limbah padat kelapa sawit 3780 g/plot dan NPK Organik 60 g/tanaman. Pengaruh utama bokashi limbah padat kelapa sawit nyata terhadap seluruh parameter pengamatan dengan perlakuan terbaik pada pemberian bokashi limbah padat kelapa sawit 3780 g/plot. Pengaruh utama NPK Organik nyata terhadap seluruh 
parameter pengamatan dengan perlakuan terbaik pada pemberian NPK Organik 60 g/tanaman.

Kata kunci: keterpaduan, perubahan, rantai persediaan, tanggapan, tantangan.

\section{PENDAHULUAN}

Menurut Pahan (2008), industri kelapa sawit di Indonesia merupakan salah satu industri yang strategis. Prospek perkembangan industri kelapa sawit saat ini sangat pesat dimana terjadinya peningkatan jumlah produksi kelapa sawit seiring menigkatnya kebutuhan manusia, salah satu contohnya adalah kebutuhan minyak kelapa sawit.

Perkembangan yang pesat ini tentu menimbulkan implikasi masalah pencemaran lingkungan. Namun demikian pencemaran yang mungkin ditimbulkan tidak akan menjadi masalah dikemudian hari jika berhasil memanfaatkan potensi pencemaran menjadi lebih berguna. Limbah yang dihasilkan dari proses pengolahan minyak kelapa sawit adalah limbah cair dan padat. Limbah padat berupa tandan kosong, Sludge dan cangkang sawit. Sementara limbah cairnya merupakan sisa dari proses pembuatan minyak yang berbentuk cair (Pambudi, 2004).

Limbah industri kelapa sawit yang sangat potensial digunakan sebagai pupuk organik dan pemantap tanah ialah limbah padat (Sludge) kelapa sawit. Limbah padat (Sludge) merupakan limbah kelapa sawit yang berbentuk padat seperti lumpur berwarna hitam kecoklatan dengan agregat remah dan sedikit lengket superti liat. Sludge dalam industri kelapa sawit, umumnya dikelola dengan sangat hati-hati melalui kolam-kolam pembuangan limbah untuk menetralisir logam-logam berat dan senyawa-senyawa berbahaya lainnya sebelum dilakukan pembuangan. Sludge yang dihasilkan industri kelapa sawit jumlahnya sangat banyak dengan persentase $70 \%$ dari seluruh jenis limbah yang dihasilkan karena berasal dari hasil pengolahan tandan kelapa sawit (Betty dan Winiati, 2007). 
Limbah agroindustri seperti sludge kelapa sawit merupakan limbah organic yang mengandung selulosa, hemiselulosa dan lignin dalam jumlah tinggi. Persentase kadar $\mathrm{C}$ tinggi dengan kandungan $\mathrm{P}$ rendah menyebabkan racio C/P tinggi. Roliadi dan Fitriasan (2011), menyatakan bahwa kandungan $\mathrm{C}$ dan $\mathrm{Ca}$ pada sludge tinggi sedangkan kandungan $\mathrm{N}, \mathrm{P}$ dan $\mathrm{K}$ rendah. Tingginya ratio $\mathrm{C} / \mathrm{N}$ dan $\mathrm{C} / \mathrm{P}$ menyebabkan imobilisasi oleh organisme. Oleh sebab itu maka perlu dicarikan penanganan limbah padat yang tepat serta bernilai ekonomis demi kebaikan lingkungan masyarakat disekitar kawasan tersebut (Kristanto, 2002).

Karakteristik limbah padat sangat bervariasi, tergantung pada bahan baku dan produk yang dihasilkan. Sumber limbah padat yang terbesar dan banyak menimbulkan permasalahan bersal dari lumpur hasil pengolahan air limbah. Lumpur yang dihasilkan dapat dibedakan atas lumpur primer yang berasal dari proses fisika-kimia, dan lumpur sekunder yang berasal dari proses biologi yang sifatnya lebih sulit didapatkan dan dipres (Kosmarayati, 2003).

Hasil penelitian Harris dkk (2013), menunjukkan bahwa sludge kelapa sawit setelah dilakukan pengelolaan didalam kolam limbah memiliki kandungan unsur hara makro dan mikro lengkap yang tergolong rendah untuk dijadikan sebagai pupuk organik. Unsur hara yang terkandung didalamnya $100 \mathrm{~kg}$ sludge antara lain $\mathrm{N}: 0,49-21 \%$, $\mathrm{P}_{2} \mathrm{O}_{5}$ : 0,26-0,46\%, $\mathrm{K}_{2} \mathrm{O}: 1,3 \%$, dan $\mathrm{Mg}: 0,64 \%$. Potensi penggunaan sludge adalah mampu meningkatkan bahan organik tanah karena berasal dari bahan organik, terciptanya perbaikan sifat fisik tanah seperti : agregat tanah, drainase dan aerase tanah, daya serap dan simpan air dan wama tanah, memperbaiki sifat kimia tanah seperti kapasitas fukar kation dan anion, menetralisir $\mathrm{pH}$ tanah, menekan kadar Al, Fe dan Mn tanah, memperbaiki sifat biologi tanah seperti meningkatkan populasi mikroorganisme dan penguraian bahan organik tanah.

Upaya pengolahan limbah padat (sludge) kelapa sawit menjadi pupuk organik seperti bokashi merupakan salah satu alternatif yang berpotensi dapat menetralisir senyawa-senyawa beracun dan meningkatkan kandungan unsur hara. Proses pembuatan limbah padat (sludge) kelapa sawit menjadi bokashi dapat dilakukan melalui proses 
fermentasi dengan pemanfaatan bio-aktivator sehingga proses dekomposisi dapat dipercepat dan senyawa komplek akan terurai menjadi sumber nutrisi dengan komposisi lebih baik (Yuwono,2005).

EM-4 (effective mikroorganisme generasi ke4) merupakan akrivator yang dapat digunakan dalam mempercepat proses fermentasi dan mengurai bahan yang sulit terurai oleh bakteri pengurai, menetralisir senyawa-senyawa beracun dan meningkatkan kandungan unsur hara dalam pupuk kompos maupun bokashi (Rahayu dan Nurhayati, 2005). EM-4 memiliki kandungan bakteri yang telah diisolasi dan bermanfaat baik dalam pembuatan pupuk organik seperti : Bakteri fotosintetik yang dapat mengubah $\mathrm{CO}_{2}$ dari udara dan hidrogen sulfida $\left(\mathrm{H}_{2} \mathrm{~S}\right)$ menjadi sumber energy dan substrat bagi bakteri atau rnikroorganisme lainnya. Bakteri asam laktat terdiri dari Laktobasillus bulgatricus, lactobasillus dan Streptococcus loctis yang mampu meningkatkan perombakan bahan organik dan menetralisir senyawa beracun dalam bahan organik (Pasa dan Agara, 2010).

EM-4 juga mengandung Ragi (yeast) seperti Aspergillus, Saccharomyces, Candida dan Hansenula yang berperan menyederhanakan amilum dan glukosa menjadi alkohol dan zat anti bakteri. Selain itu juga mengandung bakteri Acetobacter yang berperan mengubah alkohol menjadi asam cuka. Sedangkan Actinomycetes mampu mengurai bahan organik yang sulit terurai oleh bakteri lain. Sementara Jamur fermentasi seperti Aspergillus dan Penicillium dapat menguraikan bahan-bahan organik untuk meningkatkan kandungan unsur hara, alkohol, ester dan zal-zat antimikroba dalam puupk organik (Yurvono, 2005 ).

Kriteria bokashi atau kompos yang baik ialah berwarna coklat gelap sampai hitam, bersuhu dingin, berstruktur remah, kosentrasi gembur dan tidak berbau. Bokashi yang telah matang akan menyebabkan unsur-unsur yang terkandung dalam bokashi atau kompos baik makro maupun mikro lebih tinggi ketersedianya bagi tanaman dan dapat memperbaiki kondisi tanah (Nugroho, 2004).

Bokashi yang berasal dari limbah padat kelapa sawit memiliki keunggulan dari jenis bokashi dari bahan organic lainnya yaitu memiliki struktur remah dan berwarna hitam (mirip tanah), memiliki 
kemampuan menahan air tinggi, mengandung rasio $\mathrm{C} / \mathrm{N}$ rendah sehingga mudah dan cepat terurai di dalam tanah dan memiliki $\mathrm{pH}$ bersifat basa antara 8-9, 8 tergantung dari proses pembuatan dan penyimpanan (Roliadi dan Fitriasari, 2011). Hasil penelitian Yulia dan Murniati (2013), menunjukkan bahwa kandungan unsur hara bokashi dari limbah padat kelapa sawit yaitu : $\mathrm{C}: 35 \%, \mathrm{~N}: 2,34 \%, \mathrm{P}: 2,8 \%$, $\mathrm{K}: 5,53 \%$, Ca : $1,15 \%$ dan $\mathrm{Mg}: 0,96 \%$.

Selain pemupukan, faktor yang sangat penting dalam meningkatkan produksi adalah dosis pemupukan yang ditentukan berdasarkan umur tanaman, jenis tanah, kondisi penutup tanah dan kondisi visual tanaman. Rekomendasi pemupukan yang diberikan oleh Lembaga Penelitian selalu mengacu pada konsep 4T yaitu: tepat jenis, tepat dosis, tepat cara, dan tepat waktu pemupukan (Lingga dan Marsono, 2007). Hasil penelitian Siregar (2007), menunjukkan bahwa pemanfaatan bokashi sludge kelapa sawit berpengaruh nyata terhadap pertumbuhan dan produksi kacang hijau dengan dosis terbaik $1 \mathrm{~kg} / \mathrm{plot}$ (15 ton/ha). Menurut Nugroho (2004), penggunaan pupuk organik umumnya lebih banyak dibandingkan pupuk anorganik untuk per satuan luas lahan tertentu. Dosis pemberian pupuk organik kompos, bokashi, pupuk hijau dan kandang ayam relatif sama yaitu antara 1520 ton/hektar.

Salah satu pupuk organik yang mampu menyediakan unsur hara baik makro dan mikro serta memperbaiki kondisi fisik, kimia dan biologi tanah yaitu pupuk NPK organik sehingga serapan unsur hara oleh tanaman lebih efektif dan efisien yang mampu menurunkan potensi kekahatan hara pada tanaman (Musnawar, 2003).

Pupuk NPK organik mempunyai kandungan Nitrogen 6,45\%, $\mathrm{P}_{2} \mathrm{O}_{5} 0,93 \%, \mathrm{~K}_{2} \mathrm{O} 8,86 \%$, C-Organik 3,1\%, Sultur 1,60 \%, CaO 4,10 $\%, \mathrm{MgO} 1,70 \%, \mathrm{Cu} 33,98$ ppm, Zn 134,94 ppm, Besi 0,22 \%, dan Boron 94,75 ppm (Anonimous, 2006). Adapun kelebihan dari pupuk NPK organik adalah 1). mengandung unsur hara makro dan mikro lengkap. 2). Dapat memperbaiki struktur tanah, sehingga tanah menjadi gembur. 3). Memiliki daya simpan air yang tinggi. 4). Beberapa tanaman yang di pupuk dengan pupuk organik lebih tahan terhadap serangan penyakit. 5). Meningkatkan aktifitas mikroorganisme tanah yang menguntungkan. 6). Memiliki 
effecresidual positif, sehingga tanaman yang ditanam pada musim berikutnya tetap bagus dalam pertumbuhan dan produktivitasnya serta 7). Dapat diberikan baik sebagai pupuk dasar maupun susulan.

Hasil penelitian Nugroho (2004), menunjukkan bahwa pemberian pupuk NPK organik $20 \mathrm{~g} /$ tanaman mampu memberikan pengaruh terbaik terhadap tinggi tanaman, diameter batang, jumlah batang primer, umur saat muncul bunga, umur panen pefiama, dan jumlah buah pada tanaman tomat. Penelitian Anjarwati (2014), menunjukkan bahwa pemberian NPK Organik $950 \mathrm{~kg} / \mathrm{Ha}$ mampu memberikan pengaruh terbaik terhadap tinggi, umur berbunga, umur panen, jumlah buah per tanaman, berat buah per tanaman dan jumlah buah sisa tanaman terung telunjuk.

\section{METODE PENELITIAN}

Penelitian telah dilaksanakan di kebun percobaan Fakultas Pertanian Universitas Islam Riau, Jalan Kaharudin Nasution KM 11, Kelurahan SimpangTiga, Kecamatan Bukit Raya, Kota Pekanbaru. Penelitian telah dilakukan selama 5 (lima) bulan terhitung bulan Januari sampai Mei 2015 (Lampiran 1).

Bahan yang digunakan adalah benih terung ungu (varietas hibrida Fl), bokashi limbah padat kelapa sawit, pupuk kandang ayam, pupuk NPKorganik, EM- 4, bawang putih, gula, kayu, cat minyak dan paku ukuran 3 inci. Sedangkan alat-alat yang digunakan adalah :cangkul, gembor, timbangan, meteran, kamera, parang, ember dan alat-alat tulis.

Penelitian menggunakan rancangan percobaan $4 \times 4$ faktorial dalam Rancangan Acak Lengkap (RAL). Faktor-faktor tersebut adalah faktor L (dosis bokasi limbah padat sawit) dan faktor N (dosis pupuk NPK Organik) yang masing-masing terdiri dari empat taraf sehingga diperoleh 16 kornbinasi perlakuan. Setiap kombinasi perlakuan terdiri dari 3 kali ulangan, sehingga terdapat 48 satuan percobaan. Seliap satuan pecobaan terdiri 4 tanaman dan 2 diantaranya sebagai sampel. Jumlah tanaman seluruhnya adalah 192 tanaman. Adapun factor Lyaitudosis pemberian bokashi limbah padat kelapa sawit yang terdiri 
dari :

L0 = Tanpa bokasi limbah padat kelapa sawit

$\mathrm{L} 1=1260 \mathrm{~g} /$ plot $(7,5$ ton $/$ tra $)$

$\mathrm{L} 2=2520 \mathrm{~g} / \mathrm{plot}(15 \mathrm{ton} / \mathrm{ha})$

L3 $=3780 \mathrm{~g} / \mathrm{plot}(22,5 \mathrm{ton} / \mathrm{ha})$

Faklor N yaitu dosis pemberian pupuk NPK organik yang terdiri dari:

N0 = Tanpa dosis pupuk NPK Organik

$\mathrm{N} 1=20 \mathrm{~g} /$ tanaman

$\mathrm{N} 2=40 \mathrm{~g} /$ tanaman

$\mathrm{N} 3=60 \mathrm{~g} /$ ltanaman

Dari faktor-faktor perlakuan tersebut akan diperoleh kombinasi perlakuan seperti pada Tabel 1 .

Tabel 1. Kombinasi Perlakuan Dosis Bokasi Limbah Padat Kelapa Sawit dan NPK Organik pada tamanan terong.

\begin{tabular}{|c|c|c|c|c|}
\hline \multirow{2}{*}{$\begin{array}{c}\text { Perlakuan } \\
\text { L }\end{array}$} & \multicolumn{4}{|c|}{ Perlakuan N } \\
\cline { 2 - 5 } & $\mathrm{N}_{0}$ & $\mathrm{~N}_{1}$ & $\mathrm{~N}_{2}$ & $\mathrm{~N}_{3}$ \\
\hline $\mathrm{L}_{0}$ & $\mathrm{~L}_{0} \mathrm{~N}_{0}$ & $\mathrm{~L}_{0} \mathrm{~N}_{1}$ & $\mathrm{~L}_{0} \mathrm{~N}_{2}$ & $\mathrm{~L}_{0} \mathrm{~N}_{3}$ \\
\hline $\mathrm{L}_{1}$ & $\mathrm{~L}_{1} \mathrm{~N}_{0}$ & $\mathrm{~L}_{1} \mathrm{~N}_{1}$ & $\mathrm{~L}_{1} \mathrm{~N}_{2}$ & $\mathrm{~L}_{1} \mathrm{~N}_{3}$ \\
\hline $\mathrm{L}_{2}$ & $\mathrm{~L}_{2} \mathrm{~N}_{0}$ & $\mathrm{~L}_{2} \mathrm{~N}_{1}$ & $\mathrm{~L}_{2} \mathrm{~N}_{2}$ & $\mathrm{~L}_{2} \mathrm{~N}_{3}$ \\
\hline $\mathrm{L}_{3}$ & $\mathrm{~L}_{3} \mathrm{~N}_{0}$ & $\mathrm{~L}_{3} \mathrm{~N}_{1}$ & $\mathrm{~L}_{3} \mathrm{~N}_{2}$ & $\mathrm{~L}_{3} \mathrm{~N}_{3}$ \\
\hline
\end{tabular}

Data hasil pengamatan dari masing-masing perlakuan kemudian akan dianalisis secara statistik menggunakan analisis sidik ragam. Jika $\mathrm{F}$ hitung lebih besar dari $\mathrm{F}$ tabel maka akan dilanjutkan dengan uji Beda Nyata Jujur (BNJ) pada taraf 5\%.

\section{Parameter Pengamatan}

1. Tinggi Tanaman (cm)

Pengamatan tinggi tanaman dilakukan satu kali selama penelitian yaitu pada akhir pertumbuhan vegetatif. Pengukuran dilakukan dengan cara mengukur dari bagtan pangkal batang (permukaan tanah) sampai ke titik tumbuh tanaman terung. Pengukuran dilakukan dengan menggunakan meteran. Data hasil pengamatan yang diperoleh kemudian dianalisis secara statistik dan disajikan 
dalam bentuk tabel.

2. Umur Berbunga (hari)

Pengamatan umur berbunga dilakukan dengan cara menghihrng jumlah hari sejak penanaman hingga tanaman mengeluarkan bunga dengan kriteria > 507 oper plotnya telah berbunga. Data hasil pengamatan yang diperoleh kemudian dianalisis secara statistik dan disajikan dalam bentuk tabel.

3. Umur Panen (hari)

Pengamatan umur panen pertama dilakukan dengan cara menghitung jumlah hari sejak penanaman di lapangan hingga tanaman telah menunjukkan $>50 \%$ per plotnya telah memenuhi kreteria panen. Data hasil pengamatan yang diperoleh kemudian dianalisis sccara statistik dan ditampilkan dalam bentuk tabel.

4. Jumlah Buah Ekonomis Per Tanaman (Buah)

Pengamatan dilakukan dengan cara menghitung seluruh jumlah buah ekonomis yang dipanen selama 5 kali panen pada masingmasing tanaman sampel. Data hasil pengamatan yang diperoleh kemudian dianalisis secara statistik dan disajikan dalam bentuk tabel.

5. Berat Buah Ekonomis Per Tanaman (g)

Pengamatan berat buah dilakukan dengan cara menjumiahkan seluruh berat buah ekonomis yang dipanen mulai dari pnen ke-1 hingga panen ke 5 pada masingmasing tanaman sampel. Data hasil pengamatan yang diperoleh kemudian dianalisis secara statistik dan disajikan dalam bentuk tabel.

6. Jumlah Buah Tidak Ekonomis (g)

Pengamatan jumlah buah tidak ekonomis dengan menjumlahkan seluruh buah yang tidak ekonomis dari panen ke-3 hingga panen ke-5 pada masing masing plot. Kreteria buah terung ungu yang tidak ekonomis ialah bentuk buah tidak normal (cacat), rusak, terserang hama dan penyakit. Data hasil pengamatan yang diperoleh kemudian analisis secara statistik dan disajikan dalam 
bentuk tabel.

\section{HASIL DAN PEMBAHASAN}

\section{A. Tinggi Tanaman (cm)}

Data hasil pengamatan tinggi tanaman terung setelah dianalisis sidik ragam (Lampiran 4.a), menunjukkan bahwa baik interaksi maupun pengaruh utama pemberian bokashi limbah padat kelapa sawit dan NPK Organik nyata terhadap tinggr tanaman terong. Rerata hasil pengamatan tinggi tanaman terungsetelah di uji lanjut BNJ pada taraf 5\% dapat dilihat pada Tabel 2.

Data Tabel 2, menunjukkan bahwa interaksi bokashi limbah padat kelapa sawit 3780 g/plot dan NPK Organik 60 g/tanaman (L3N3) memberikan pengaruh terbaik terhadap tinggi tanaman terung dengan tinggi tanaman $116.33 \mathrm{~cm}$, kemudian diikuti oleh pemberian bokashi limbah padat kelapa sawit $2520 \mathrm{~g} /$ plot dan NPK Organik $60 \mathrm{~g} /$ tanaman (L2N3) yaitu $112.33 \mathrm{~cm}$, perlakuan L3N2 yaitu $111.67 \mathrm{~cm}$, perlakuan L2N2 yaitu $109.33 \mathrm{~cm}$, perlakuan LIN3 yaitu $106.33 \mathrm{~cm}$ dan perlakuan kontrol (LONO) merupakan perlakuan yang menghasilkan tinggi tanaman terendah yaitu $89.33 \mathrm{~cm}$.

\section{B. Umur Berbunga (hari)}

Data hasil pengamatan umur berbunga tanaman terung setelah dianalisis sidik ragam (Lampiran 4.b), menunjukkan bahwa baik interaksi maupun pengaruh utama pemberian bokashi limbah padat kelapa sarvit dan NPK Organik nyata terhadap umur berbunga tanaman terung. Rerata hasil pengamatan umur berbunga tanaman terung setelah di uji lanjut BNJ pada taraf 5\% dapat dilihat pada Tabel 3. 


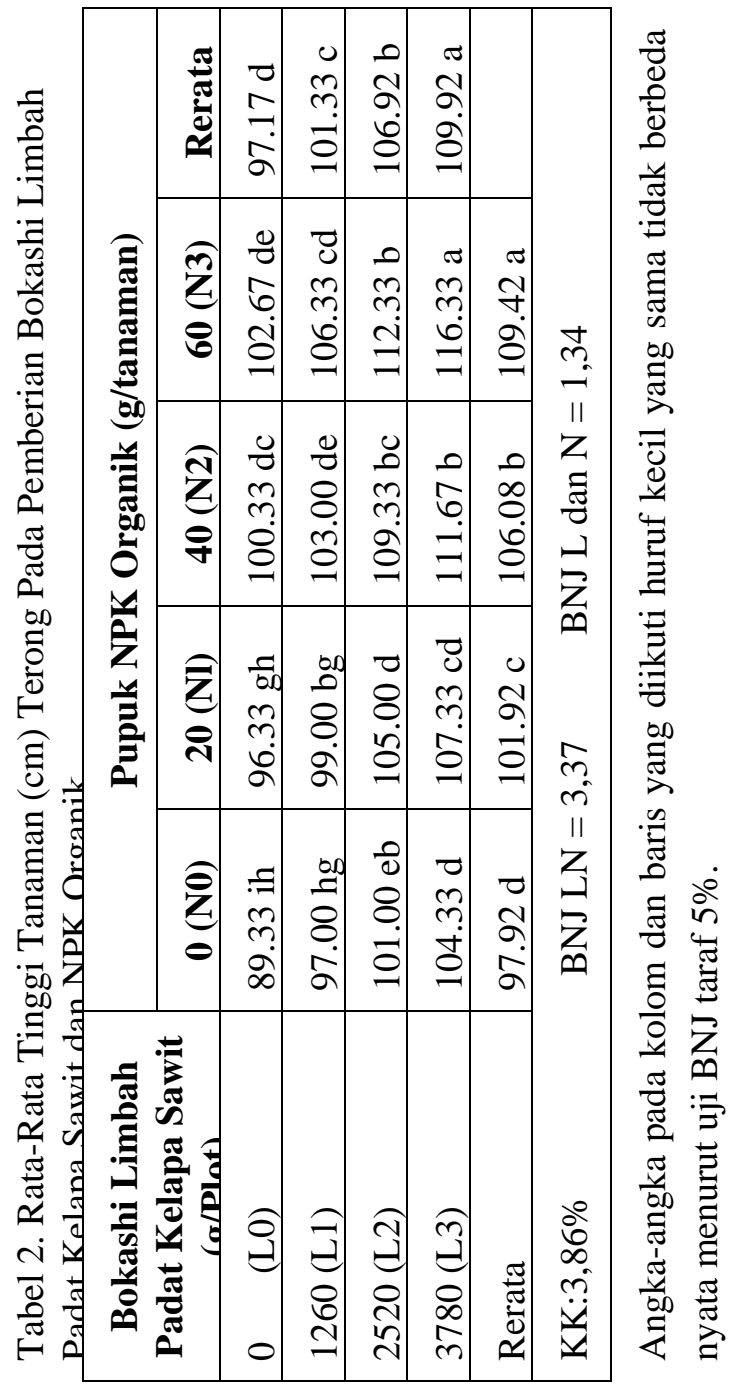


Data Tabel 3, menunjukkan bahwa pembungaan tanaman terung pada pemberian bokashi limbah kelapa sawit 3780 g/plot dan NPK Organik 60 g/tanaman (L3N3) lebih cepat dan berbeda nyata dengan perlakuan lainnya. Diduga dipengaruhi oleh kondisi pemenuhan unsur hara dan perbaikan kondisi tanah yang baik sehingga pertumbuhan dan perkembangan tanaman terung berlangsung baik dan menyebabkan inisiasi pembungaan tanaman dapat dipercepat. Sitompul dan Guritno (1995), menyatakan bahwa munculnya bunga akan lebih cepat bila laju pertumbuhan dan perkembangan tanaman berlangsung baik.

\section{Umur Panen (hari)}

Data hasil pengamatan umur panen tanaman terung setelah dianalisis sidik ragam (Lampiran 4.c), menunjukkan bahwa baik interaksi maupun pengaruh utama pemberian bokashi limbah padat kelapa sawit dan NPK Organik nyata terhadap umur panen tanaman terung. Rerata hasil pengamatan umur panen tanaman terong setelah di uji lanjut BNJ pada taraf 5\% dapat dilihat pada Tabel 4.

Data pada Tabel 4, menunjukkan bahwa interaksi pemberian bokashi limbah padat kelapa sawit dan NPK Organik memberikan pengaruh terhadap umur panen tanaman terung dimana pada kombinasi pemberian bokashi limbah kelapa sawit $3780 \mathrm{~g} /$ plot dan NPK Organik 60 gltanaman (L3N3) dapat menghasilkan umur panen yang lebih cepat yaitu 45.00 hari, kumudian diikuti oleh kombinasi perlakuan L3N2 dengan umur panen 52.33 hari, perlakuan L2N3 yaitu 52.61 hari, perlakuan L1N3 yaitu 52.67 hari, perlakuan L2N2 yaitu 53.00 hari, perlakuan L3N1 yaitu 53.00 hari dan umur panen paling lama dihasilkan oleh perlakuan kontrol LONO dengan umur panen 56.00 hari. 


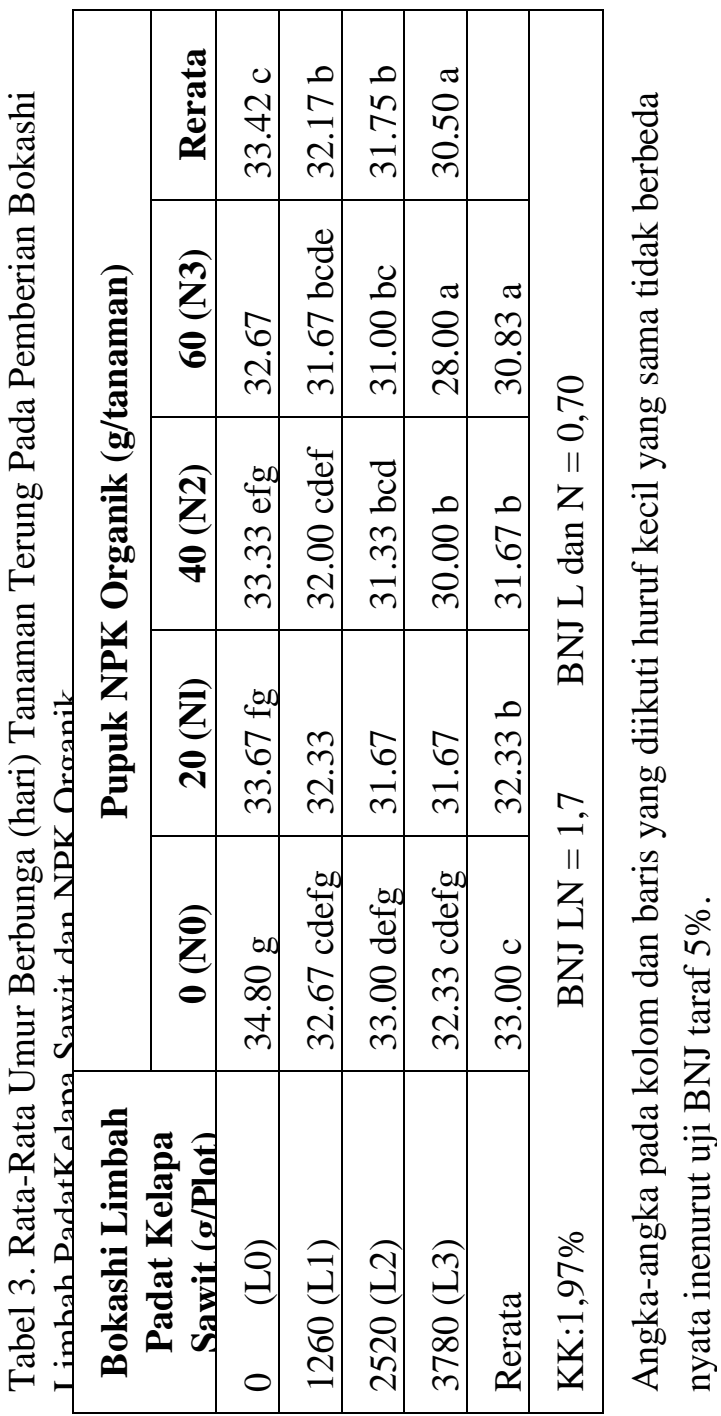




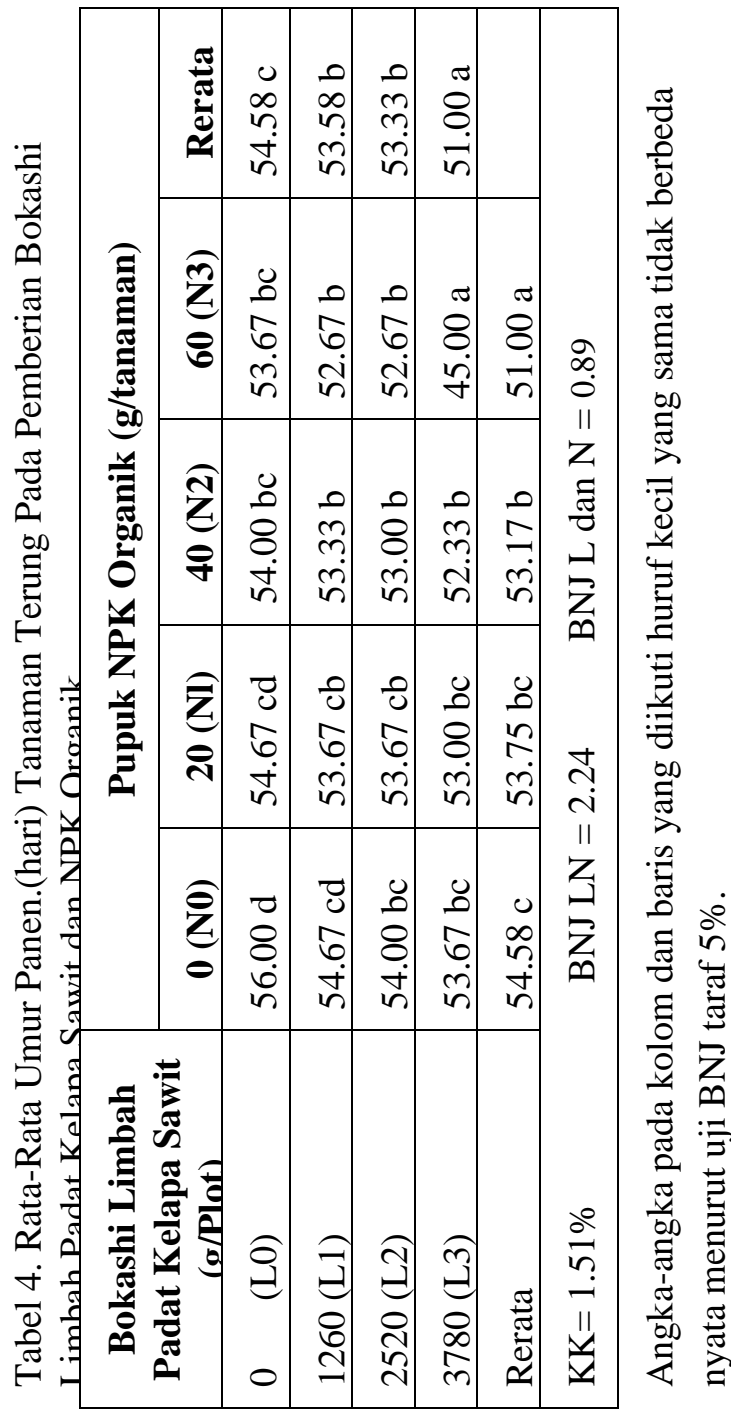




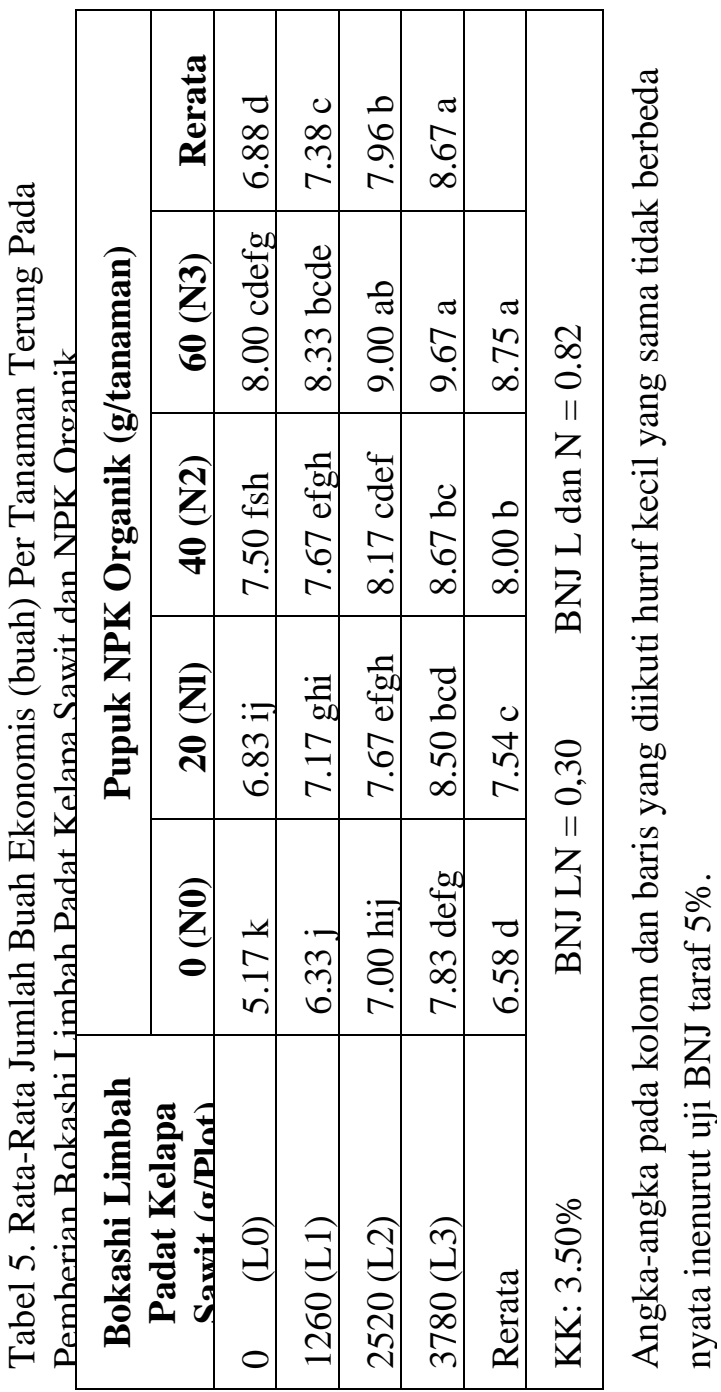




\section{Jumlah Buah Ekonomis Per Tanaman (buah)}

Data hasil pengamatan jumlah buah ekonomis setelah dianalisis sidik ragam (Lampiran 4.d), menunjukkan bahwa baik interaksi maupun pengaruh utama pemberian bokashi limbah padat kelapa sarvit dan NPK Organik nyata terhadap jumlah buah ekonomis tanaman terung. Rerata hasil pengamatan jumlah buah ekonomis tanaman terung setelah di uji lanjut BNJ pada taraf 5\% dapat dilihat pada Tabel 5.

Data pada Tabel 5,menunjukkan bahwa interaksi bokashi limbah pada kelapa sawit dan NPK Organik memberikan pengaruh terhadap jumlah buah tanaman terung, dengan perlakuan terbaik terdapat pada pemberian bokashi limbah kelapa sawit $3780 \mathrm{~g} / \mathrm{plot}$ dan NPK Organik $60 \mathrm{~g} /$ tanaman (L3N3) dengan jumlah buah 9.67 buah, tidak berbeda nyata dengan kombinasi perlakuan L2N3 dengan jumlah buah 9.00 buah, kemudian diikuti oleh perlakuan L3N2 yaitu 8.67 buah, L3N1 yaitu 8.50 buah, LIN3 yaitu 8.33 buah, L2N2 yaitu 8.17 buah, L0N3 yaitu 8.00 buah, L0N0 yaitu 8.00 buah dan jumlah buah paling sedikit dihasilkan pada perlakuan control yaitu 5.17 buah.

\section{KESIMPULAN}

1. Interaksi Bokashi limbah padat kelapa sawit dan NPK Organik berpengaruh nyata terhadap tinggi tanaman, umur berbunga, umur panen, jumlah buah ekonomis dan berat buah ekonomis per tanaman. Perlakuan terbaik pada pemberian bokashi limbah padat kelapa sawit $3780 \mathrm{~g} / \mathrm{plot}$ dan NPK Organik $60 \mathrm{~g} / \mathrm{tanaman}$ (L3N3).

2. Pengaruh utama bokashi limbah padat kelapa sawit nyata terhadap seluruh parameter pengamatan. Perlakuan terbaik pada pemberian bokashi limbah padat kelapa sawit $3780 \mathrm{~g} / \mathrm{plot}$ (L3).

3. Pengaruh utama NPK Organik nyata terhadap seluruh parameter pengamatan. Perlakuan terbaik pada pemberian NPK Organik 60 g/tanaman (N3). 


\section{DAFTAR PUSTAKA}

Anjarwati, D. 2014. Pengaruh Pemberian Pupuk NPK Organik dan Herbafarm Cair Terhadap Pertumbuhan dan Hasil Tanaman Terong Telunjuk (Solanum melogeia L). Skripsi Program Studi Agroteknologi Fakultas Pertanian Universitas Islam Riau. Pekanbaru.

Anonimous. 2011. Teknik Pemupukan dan Dosis Anjuran Pupuk

Nitrogen, Fosfat dan Kalium Pada Tanaman Pangan Lahan Kering. Balai Pengkajian Teknologi Pertanian. Biromaru. Palu.

Darjanto dan S, Satifah. 2000. Pengetahuan Dasar Biologi Bunga dan Teknik Penyerbukan. Gramedia Pustaka. Jakarta.

Direktorat Jenderal Bina Pengolahan dan Pemasaran Hasil Pertanian. 2009. Bulettin Teknopro Hortikultura Produksi Tanaman Terong Dalam Angka. Edisi 65. Departemen Pertanian. Jakarta.

Elismani. Nuwahyuni, I dan Sofya, M.Z. 20A6. Uji Pertumbuhan dan Hasil Tanaman Terong Dengan Penerapan Berbagai Media Tumbuh dan Zat Tumbuh Yang Berbeda di Sumatra Utara. Jurnal Biologi Sumatra Utara 1 (1) : 15-19. FMIPA Universitas Sumatera Utara. Medan.

Fadli. 2014. Uji Pemberian Jenis Pupuk Organik dan NPK Organik Pada Tanaman Mentimun Suri (Cucumis Sativus L). Skripsi Fakultas PertanianUniversitas Islam Riau. Pekanbaru.

Ginting, P. 2007. Sistem Pengelolaan Lingkungan Dan Limbah lndustri. Yrama Widia. Bandung.

Hadisuwito, S. 2007. Membuat Pupuk Kompos Cair. Penyunting Purwadaksi Agromedia Pustaka. Jakarta.

Hakim, L. 2012. Adaptasi Morfologis, Fisiologis dan Tingkah Laku Tumbuhan. Diperoleh dari www.blog- 
pelajaransekolah.blogspot.com. Diakses Pada 20 Mei 2015.

Harris, Anam. S dan Mahmudsyah, S. 2013. Studi Pemanfaatan Limbah Padat Dari Kelapa Sawit. Jurnal Teknik Pomits 2 (1) : 73-79 Fakultas Teknik Institut Teknologi Sepuluh November. Surabaya.

Hastuti, E. D, E. Prihastanti dan R.B Hastuti. 2000. Fisiologi Tumbuhan II. Universitas Diponegoro Press. Malang.

Mirza, F. M. 2012. Hara dan Hubungannya dengan Tanaman. Diperoleh dari http :/www. mirza.blogspot.com Diakses pada 23 Mei 2015.

Pambudi. 2004. Pengelolaan Limbah Industri dan Rumah Tangga. Rineka Cipta. Jakarta.

Roliadi, H dan Fatriasari, W. 2011. Kemungkinan Pemanfaatan Tandan Kosong Kelapa Sawit Sebagai Bahan Baku Pembuatan Pupuk Organik Berkelanjutan Universitas Sriwijaya. Palembang.

Rukmana. 1994. Teknis Budidaya Tanaman Terong. Penebar Swadaya. Jakarta.

Siregar, H. 2007. Pengujian Bokashi Limbah Padat (Sludge) Kelapa Sawit Terhadap Pertumbuhan dan Produksi Varietas Kacang Hijau (Vigna Radiata L) Diperoleh dari wwrv.respository.usu.ac.id. Diakses pada 20 Mei 2015. 